\title{
DESTABILIZING INTERVENTION IN EU DAIRY MARKETS
}

\author{
Jakub Olipra ${ }^{\bowtie}$ \\ Warsaw School of Economics, Poland
}

\begin{abstract}
Butter and skimmed milk powder (SMP) are considered to be primary dairy commodities as they enable storage of fat and protein. The spread between butter and SMP prices in the European Union (EU) has been stable for many years. However, in 2016, butter prices suddenly increased to reach extremely high levels while SMP prices remained low. As a consequence, the price spread between milk fat and protein has surged, leading to severe imbalance in the EU dairy market. Some professionals argue that the main reason for this occurrence are large intervention stocks of SMP accumulated by the European Commission (EC) which weigh on prices. Nevertheless, no one has yet proved the existence of a causal relationship between the intervention stocks accumulated by the EC and the butter/SMP price spread. Hence, the purpose of this paper is to test that hypothesis. The causality between the EC intervention stocks and the butter/SMP price spread was tested using the Granger causality approach. The results show that the difference between butter and SMP intervention stocks accumulated by the EC Granger-causes the butter/SMP price spread while there is no causality in the opposite direction, which supports the hypothesis tested.
\end{abstract}

Keywords: CAP, intervention, butter, SMP, dairy, Granger causality

\section{INTRODUCTION}

Butter and skimmed milk powder (SMP) enable longterm storage of milk fat and milk protein, the two most valuable components of raw milk. Therefore, butter and SMP are considered as primary dairy commodities (O'Connor et al., 2009). The spread between butter and
SMP prices in the European Union (EU) has been stable for many years (see Fig. 1). Nevertheless, in 2016, butter prices suddenly increased to reach extremely high levels while SMP prices remained low. As a result, the price spread between butter and SMP hit EUR 477.10 in September 2017 vs. the average level of EUR 96.91 recorded in 2009-2015 (see Fig. 1). There is an intense discussion among dairy sector professionals about the reasons behind these developments.

Some of the representatives of the dairy sector consider that a significant increase in the butter/SMP price spread results from the surge in global demand for butter (Terazono, 2017; Gale, 2018). They argue that after years of decline, the demand for butter is growing due to increasing consumer interest in natural ingredients and the bad press for vegetable oil-based fats. Nonetheless, such an explanation is not confirmed by global data on butter demand. According to OECD-FAO (2018), global butter consumption increased by $2.1 \%$ in 2017 (vs. $2.0 \%$ in 2016), and the growth rate is consistent with the longterm trend observed in the last decade (2.2\%).

Some market participants attribute the strong increase in the butter/SMP price spread to herding behavior and speculation. As most transactions on the dairy market are on an over-the-counter (OTC) basis, there is a relatively high asymmetry of information. Fueled by media, widespread expectations on further rise in butter prices might have encouraged producers and consumers to stockpile butter which boosted an increase in its prices. Nevertheless, the above hypothesis is not reflected by data on ending stocks of butter provided by

\footnotetext{
\akub Olipra, Collegium of Management and Finance, Warsaw School of Economics, Madalińskiego 6/8 St., 02-513 Warsaw, Poland, e-mail: jakub.olipra@sgh.waw.pl, https://orcid.org/0000-0001-9216-6056
} 
Butter and SMP prices in EU

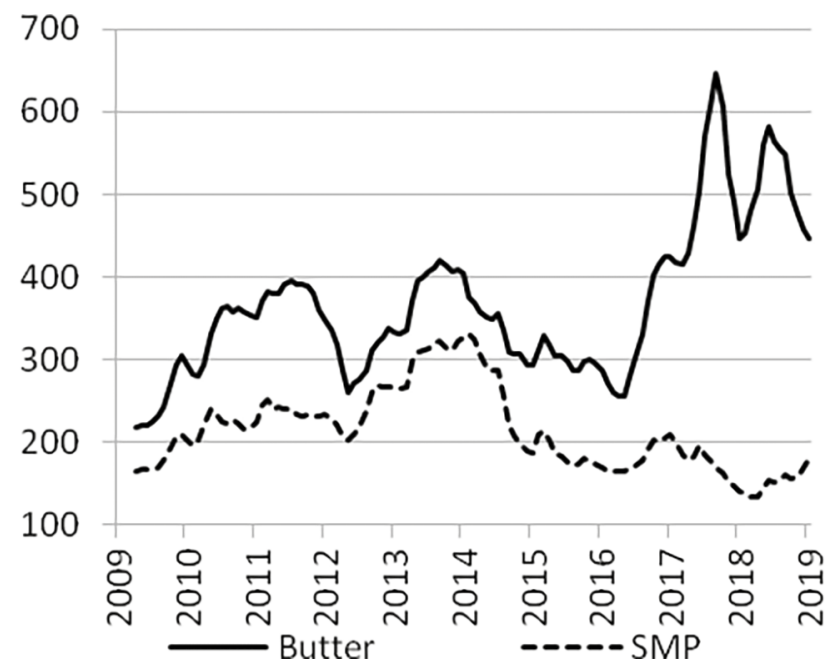

Butter and SMP price spread

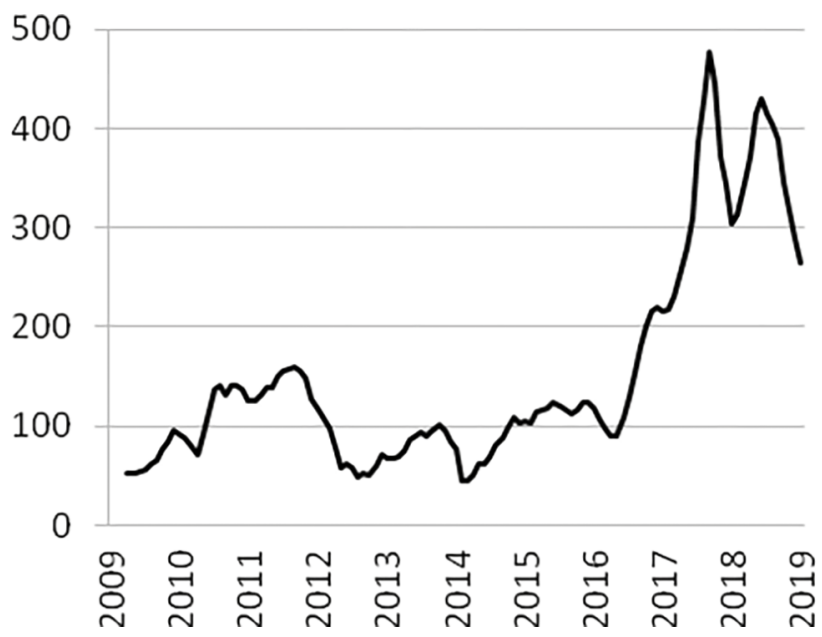

Fig. 1. Price developments in the EU butter and SMP markets (EUR per ton, monthly data) Source: elaborated based on the EU Milk Market Observatory, 2018.

OECD-FAO (2018). As far as financial speculation is considered, current research indicates that there is no strong evidence for a causal relationship between speculative capital flows and commodity prices (Amann et al., 2013). Hence, it may be assumed that the dairy market is not an exception.

The last and most robust explanation for the strong increase in the butter/SMP price spread discussed among professionals are abundant intervention stocks of SMP accumulated by the European Commission (Schreijen and Bellamy, 2017). At the end of 2017, the European Commission's (EC) intervention stocks of SMP amounted to 378.1 thousand tons i.e. ca. $17 \%$ of annual global SMP exports. The influence of SMP intervention stocks on the butter/SMP price spread is considered to be twofold. Firstly, the abundant intervention stocks of SMP directly dampen the SMP prices which is consistent with the commodity storage theory (Williams and Wright, 1991). Secondly, the abundant intervention stocks of SMP may affect the butter/SMP price spread indirectly due to the impact they have on the relative profitability of production of each dairy product. Despite the fact that raw milk can be processed into a variety of products, generally the choice is between producing butter and SMP, or cheese and whey. The decision to produce more butter is not only based on the butter price but also depends on the market outlook for SMP and on cheese and whey prices. While butter prices are record high, the low levels for SMP mean the returns on butter/SMP and cheese/whey are similar. Supportive for a such conclusion are similar values of the Actual Milk Price Equivalent (AMPE) and the Milk for Cheese Value Equivalent computed by the AHDB Dairy for the United Kingdom which may be treated as a proxy for profitability of butter/SMP and cheese/whey production, respectively. The British dairy market is strongly integrated with the whole EU dairy market, hence the results for the UK can be generalized on the whole EU. The outlook for SMP prices is highly uncertain due to abundant EC intervention stocks, and butter prices are very volatile and suspiciously high. This makes many dairy professionals unwilling to take a risk and produce butter/SMP; as a consequence, they may switch to cheese/whey production.

Therefore, the aim of this paper is to test the hypothesis if the abundant stocks of SMP accumulated by $\mathrm{EC}$ are the reason for the imbalance in the dairy market reflected by the surge in the butter/SMP price spread. In a more general approach, the focus of this study is on the impact of interventionist inventory schemes in the EU milk market, financed by EU taxpayers, on dairy prices. As this problem is largely associated with the dairy processors' decisions on production structure, the study assumes the perspective of dairy processors. 


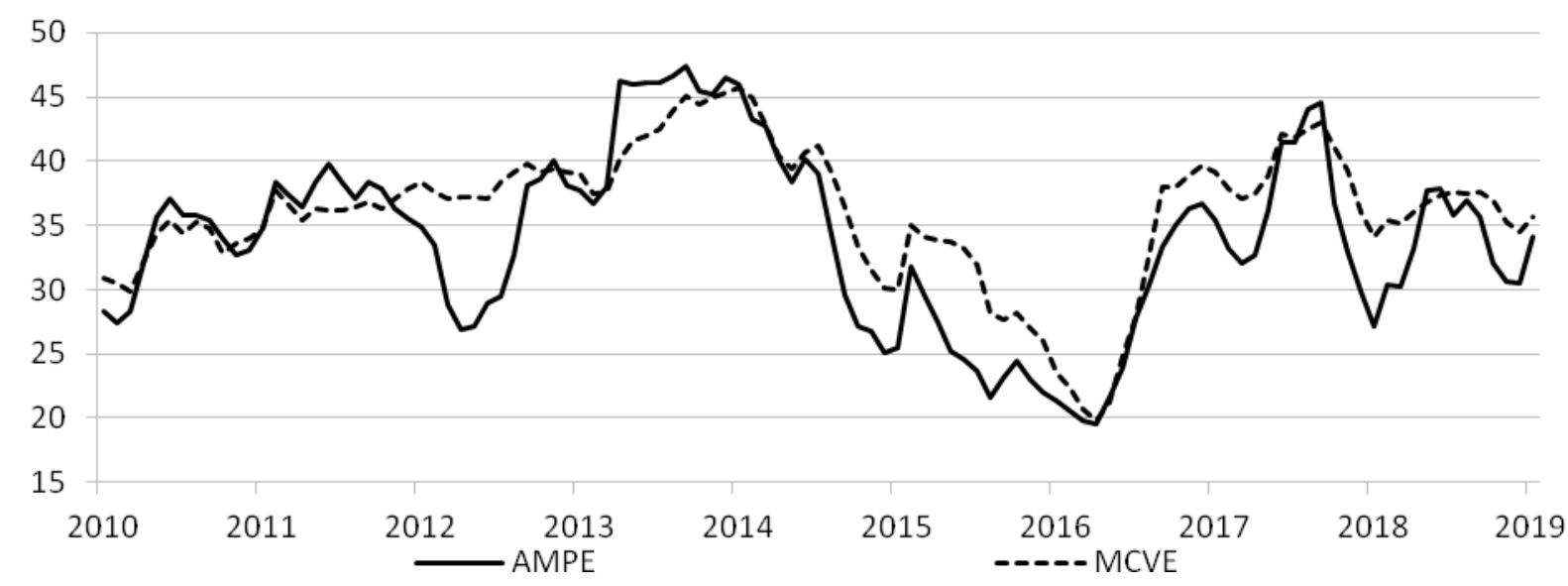

Fig. 2. Historical relationships between $A M P E$ and MCVE in the UK (EUR/100 kg, monthly data) Source: calculated based on AHDB/DairyCo, 2014.

The paper is organized as follows. Section 2 provides a literature review on the EU policy for the dairy market. Section 3 briefly describes the technical background behind the EC interventions. Section 4 presents data collection methods used in the research. Section 5 describes the econometric methods employed in the research and the results of the estimations. Section 6 shows the estimation results. Section 7 presents the concluding remarks and policy implications.

\section{LITERATURE REVIEW}

There is a vast literature on the Common Agricultural Policy (CAP) and its implications for prices of dairy commodities. It mainly focuses on the deregulation of the EU milk market and its effect on price volatility (Keane and O'Connor, 2009; O'Connor et al., 2009; Weber et al., 2012; O'Connor et al., 2015; Pouch and Trouvé, 2018; Olipra, 2019). The main conclusion from the existing literature is that prior to the fundamental reform of the dairy policy under the Luxembourg agreement in 2003, the EU's internal dairy market was truly isolated from the global market. It was possible due to numerous internal measures such as intervention purchases, export refunds, import tariffs, production quotas and subsidized consumption. As a consequence, the prices of raw milk and dairy commodities in EU were markedly higher than abroad while the EU internal market was protected from a higher price volatility observed in the global dairy market. The gradual deregulation of the EU dairy market after the 2003 Luxembourg agreement contributed to narrowing the gap between EU and world dairy prices. As a consequence, EU prices started to be strongly correlated with global prices, resulting in a higher volatility.

The issue of higher volatility of dairy prices in the EU and its implications for risk management in the dairy sector was examined by Kloosterboer (2016). He pointed out that there is less and less room for interventionist measures in the EU dairy market. Therefore, the need arises to develop market-based risk management measures such as futures/options, voluntary insurance schemes or fiscal measures in order to build reserves in times of high prices to use them during the market downturn. The study on the development of the futures/options market for the EU dairy sector was provided in an EC report (EC, 2017). It concludes that financial tools, such as futures and options, could contribute to reducing the risks faced by dairy farmers and processors, especially in times of relatively high volatility and low prices. Nevertheless, it points out possible limitations to this solution such as low liquidity or insufficient financial background among dairy sector representatives. Moreover, dairy products are not as homogenous as grains; this additionally hampers the development of liquid futures and options markets for the dairy sector.

The dependence between the EC's intervention tools and dairy products prices was analyzed only by Heleine et al. (2016). They used the Aglink-Cosimo model to 
assess the potential impact of raising the dairy intervention prices. The results indicate that raising the intervention prices to their pre-reform level could lead to an important accumulation of intervention stocks over time. Furthermore, the results show that as the EU dairy market is currently very integrated with the world market, the higher intervention prices might result in triggering an intervention being a consequence of market imbalances driven by oversupply in other regions of the world than the EU.

The issue of abundant SMP intervention stocks accumulated by the European Commission was investigated by (Jongeneel et al., 2018). They analyzed three main EU destocking strategies for SMP. The first strategy analyzed is based on a fixed sales pattern of monthly sales of 20 thousand tons during a 1.5 -year period. The second strategy implies denaturation of the SMP so that it is no longer suitable for human consumption and that it would be sold as a protein source for animal feed. The third strategy assumes splitting up the SMP stocks into two categories, taking into account their shelf life. The first category may be sold as a fresh product (aged less than 1.5 year), whereas the second category (aged more than 1.5 year) has a lower market attractiveness which would need a price discount.

\section{INTERVENTIONS IN EU DAIRY MARIKET}

\section{Public intervention}

After the abolition of milk quotas in April 2015, intervention buying-in remains the main CAP tool for the dairy market. It is intended to provide a minimum level (referred to as a safety net) for farmgate milk prices in times of market downturn. As raw milk is itself a perishable and non-storable product, intervention purchases are based on the procurement of SMP and butter which enable long-term storage of milk fat and protein, the two most valuable components of raw milk. Therefore, intervention buying-in affects farmgate milk prices indirectly, by supporting SMP and butter prices. The intervention scheme allows the EC to buy-in 109,000 tons of SMP and 60,000 tons of butter between March 1 and September 30 each year, at the fixed reference price of EUR 1,698 per ton and EUR 2,217 per ton, respectively. After the volume limit is reached, the EC can continue buying for intervention through tenders without price guarantee. When the price situation improves, the EC can sell its intervention stocks in such a way as to avoid any disturbance of the market (Council Regulations No. 1308/2013 and No. 1370/2013).

\section{Private storage}

Another CAP tool for the dairy market is Private Storage Aid (PSA). It is based on subsidizing the private storage of butter and SMP (comprising a fixed rate per ton, plus a defined daily amount per ton) which allows to take these products temporarily off the market. The intervention scheme enables subsidized storage of the abovementioned products for a minimum period of 90 days and a maximum of 210 days. PSA differs from public intervention as the products under PSA remain the property of producers who are responsible for selling them once the contractual storage period has elapsed (Council Regulations No. 1308/2013 and No. 1370/2013).

\section{Evolution of public and private intervention stocks}

In Q1 2014, the global milk market entered the decreasing phase of the cycle. The reasons were a decline in global demand for dairy products, especially in China, and the overproduction of milk in main dairy exporting countries (including New Zealand and EU). The market prospects worsened markedly after Russia, the second largest global importer of dairy products, imposed an embargo on food exports, including dairy products from the EU, the U.S., Australia, Canada and Norway in August 2014. In response to the threat of market disruption due to the loss of the Russian export market, the EC launched the PSA on September 5, 2014.

After the abolition of milk quotas in $\mathrm{EU}$ in April 2015, the market situation deteriorated further as EU farmers markedly increased their milk deliveries. As a consequence, PSA was extended until September 30, 2016. Moreover, when SMP prices reached their intervention levels in August 2015, public intervention started in the SMP market. Intervention buying of SMP quickly exceeded the limits set for purchases with fixed price, and the EC continued intervention purchases through tenders without price guarantee. It is worth noting that in the meantime, butter price remained above the intervention levels. Due to the deteriorating market situation and high interest of producers in intervention buying-in, the EC decided in June 2016 to increase the public intervention ceiling for fixed-price intervention purchases with 132,000 tons (Council Regulation No. 2016/1042). 
In Q2 2016, there was a turning point in the global milk market cycle; prices of dairy commodities started to increase, supported mainly by lower milk production in the EU and the recovery of global demand for dairy products, especially in China. While private butter inventories were quickly released to the market due to a strong rise in prices, only a slight increase in SMP prices prevented the EC from selling its abundant intervention stocks. Moreover, the EC decided to extend the PSA for SMP until February 28, 2017.

When the market prospects deteriorated again in Q3 2017, mainly due to a strong rebound in milk production in the EU and New Zealand, public SMP inventories started to grow again. In order to prevent a further accumulation of SMP intervention stocks, the EC has implemented a temporary change to the buying-in ceiling for SMP, reducing it to zero for the 2018 window (Council Regulation No. 2018/147). Moreover, the EC started to gradually sell its SMP stocks below the intervention price level and managed to reduce them to 103,977 tons at the end of January 2019 (Commission Implementing Regulation No. 2017/1919).

Figure 3 shows how public and private stocks of SMP and butter have changed over time. Taking into consideration the historical development of butter and SMP intervention stocks presented in Fig. 3, it is worth noting that the storage of SMP used to appear only in response to the EC program, while the private storage of butter was, in some cases, also the result of a fully private initiative driven by the expectations of a higher return.

\section{DATA COLLECTION AND TRANSFORMATION}

This paper relies on data on private and public intervention stocks of SMP and butter collected by the EC, and the average prices of these commodities in EU. All time series used in the research come from the EU Milk Market Observatory. Public intervention stocks are expressed in tons while prices are nominated in euro (EUR). Price data is reported on a weekly basis whereas data on intervention stocks is released monthly. Therefore, monthly averages were calculated for the price time series to align it with intervention stocks data. The period covered by the sample is April 2009 to January 2019. The reason for adjusting the sample was to obtain the longest possible and relatively homogeneous time series. As the deregulation process of the EU dairy industry has been evolving over last two decades, it is difficult to avoid structural breaks in the study period. The period covered by the sample was marked by constant butter and SMP intervention prices, and a strong and stable integration between the EU and the global dairy market (Newton, 2016). Moreover, the study period starts with the first milk quota year after the Health Check of the Common
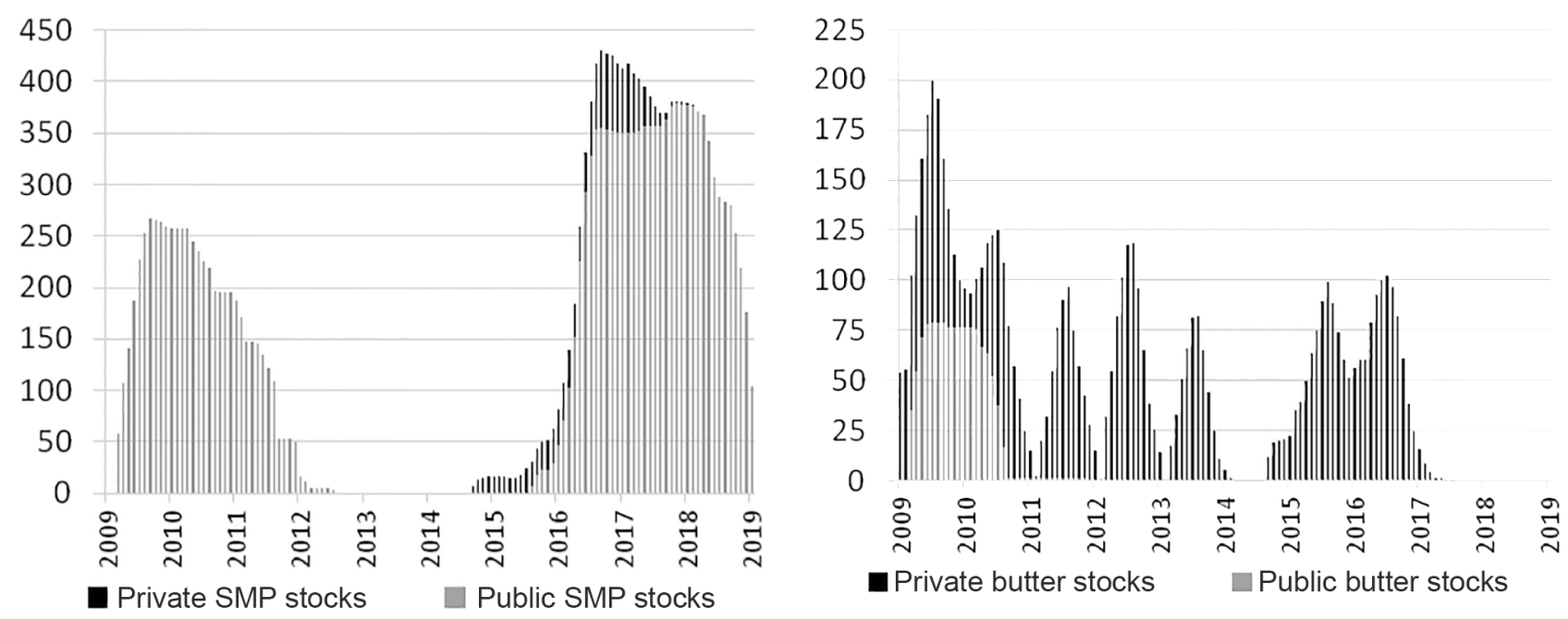

Fig. 3. Evolution of private and public butter and SMP intervention stocks in the EU (thousand tons, monthly data) Source: elaborated based on the EU Milk Market Observatory, 2018. 
Table 1. Descriptive statistics for Price Spread and Stocks Difference

\begin{tabular}{lllll}
\hline \multicolumn{1}{c}{ Variable } & \multicolumn{1}{c}{ Min } & Median & Mean & \multicolumn{1}{c}{ Max } \\
\hline Price Spread (EUR/100 kg, seasonally adjusted) & 41.327 & 116.324 & 153.307 & 441.466 \\
Stocks Difference (tons, seasonally adjusted) & -1933.793 & 288.557 & 809.222 & 4528.604 \\
\hline
\end{tabular}

Source: own calculations.

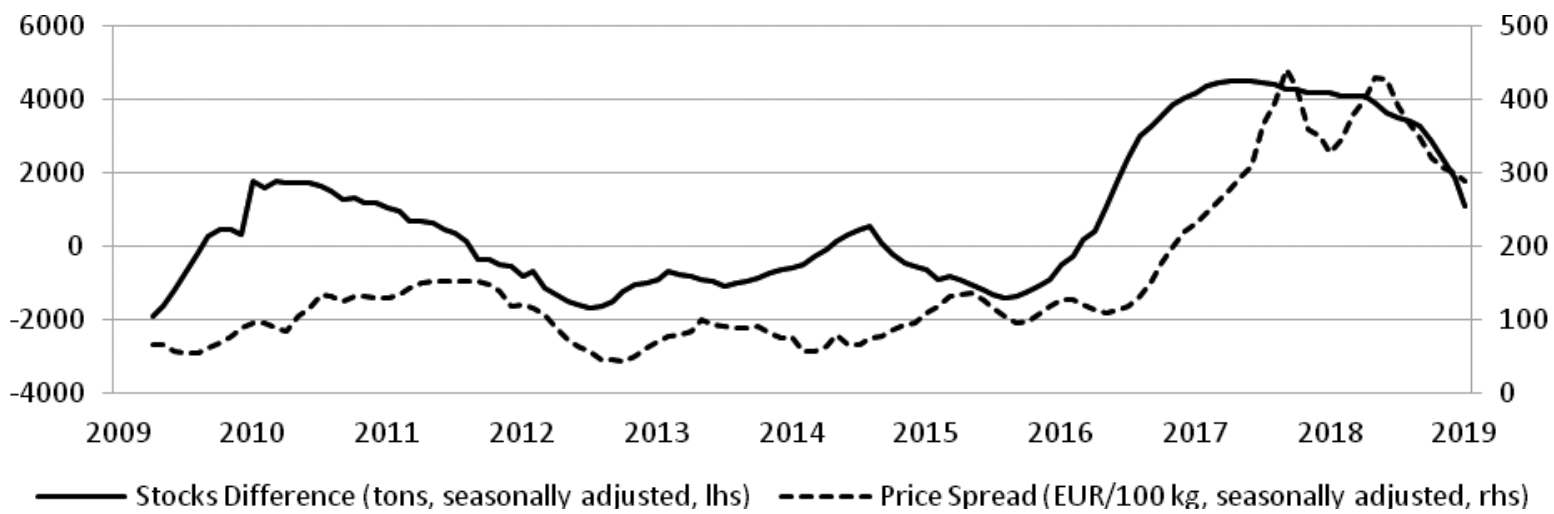

Fig. 4. Historical relationships between Price Spread and Stocks Difference (monthly data)

Source: own calculations.

Agricultural Policy in 2008 which defined the current regulatory framework for the EU milk sector, including the gradual increase in milk quotas towards their abolition in April 2015 (Kloosterboer, 2016). Therefore, the sample used in this study seems to be the best possible trade-off between length and homogeneity of the time series.

As the aim of the research is to investigate if the imbalance in the EC intervention stocks affects the spread between butter and SMP prices, the following variables were calculated and used in the estimations. The first variable is the Price Spread which reflects the difference between butter and SMP prices.

$$
\text { Price Spread }_{t}=\text { Butter proce }_{t}-\text { SMP price }_{t}
$$

The second variable is Stocks Difference which shows the relative difference between total (private and public) SMP intervention stocks and total butter intervention stocks. In order to subtract butter stocks from SMP stocks, all stocks were expressed in milk equivalent, namely in the quantity of milk needed to produce them. It may be assumed that ca. $20.94 \mathrm{~kg}$ and $11.34 \mathrm{~kg}$ of raw milk is needed to produce $1 \mathrm{~kg}$ of butter $(82 \%$ fat content) and SMP, respectively. Hence, the variable Stocks Difference was expressed as follows:

\section{Stocks Difference $_{t}=$ SMP total stocks $s_{t} \cdot 11.34-$ Butter total stocks $\cdot 20.94$}

As both intervention stocks and prices exhibit seasonality, the variables were seasonally adjusted using the additive version of the Census X-12 procedure (U.S. Census Bureau, 2011). Table 1 reports the descriptive statistics for the variables used in the research. Figure 4 shows the historical relationships between them.

\section{METHODOLOGY AND RESULTS}

The main purpose of this research is to test if the difference between the EC intervention stocks of butter and SMP affects the spread between prices of these two commodities. One of the most popular econometric tools used for testing both the dependence between variables and its direction is the Granger causality test (Granger, 1988). In the Granger causality approach, $x$ is a cause of $y$ if lagged values of $x$ are useful in forecasting $y$. Granger causality cannot be treated as causality 
Table 2. ADF and KPSS unit root tests results

\begin{tabular}{lcccc}
\hline \multirow{2}{*}{ Variable } & \multicolumn{2}{c}{ ADF } & \multicolumn{2}{c}{ KPSS } \\
\cline { 2 - 5 } & Level & $\begin{array}{c}\text { First } \\
\text { difference }\end{array}$ & Level & $\begin{array}{c}\text { First } \\
\text { difference }\end{array}$ \\
\hline Price Spread & -1.360 & -5.457 & 0.747 & 0.126 \\
Stocks Difference & -2.079 & -2.843 & 0.559 & 0.114 \\
\hline \multicolumn{1}{c}{ Test critical values } & $1 \%$ level & $5 \%$ level & $10 \%$ level & \\
\hline ADF & -3.488 & -2.887 & -2.580 & \\
KPSS & 0.739 & 0.463 & 0.347 & \\
\hline
\end{tabular}

Source: own calculations.

in the broad sense; but when coupled with economic theory, it enables drawing conclusions on the relationship between two variables. The Granger causality test is based on VAR-type regression given by:

$y_{t}=\alpha_{0}+\alpha_{1} y_{t-1}+\ldots+\alpha_{p} y_{t-p}+\beta_{1} x_{t-1}+\ldots+\beta_{p} x_{t-p}+\varepsilon_{t}(1)$

where $\alpha$ and $\beta$ are coefficients, while $p$ represents the maximum lag of variables tested. The null hypothesis is that $\beta_{1}=\beta_{2}=\ldots=\beta_{p}=0$ which means that $x$ does not Granger-cause $y$.

The ordinary Wald test of joint significance of regression parameters, used as a causality test, is not valid if the variables are non-stationary because the test statistic does not have its usual asymptotic distribution (Toda and Phillips, 1993). Therefore, in the first step of the analysis, the augmented Dickey-Fuller (ADF) and the Kwiatkowski-Phillips-Schmidt-Shin (KPSS) tests were used to check the order of integration of the variables. The results indicate that Price Spread and Stocks Difference are integrated of order one (see Table 2).

Such a conclusion seems to contradict the nature of the variables analyzed. Intervention stocks, by definition, should converge to zero in the medium term (after abatement of shock which triggered the intervention). As a consequence, the expected value of difference between SMP and butter intervention stocks should also be 0 . Similarly, the spread between prices, by definition, should be stationary too, as in the medium term it reflects the equilibrium between these two prices. Because of these particularities, further calculations assume that the variables are stationary, despite the results of ADF and KPSS tests. Nevertheless, in the sensitivity analysis, causality was tested on assumption that variables are integrated of order one in order to test the robustness of estimates.

The p-lag vector autoregressive VAR model was estimated in the second step. The VAR(p) model can be defined as:

$$
Y_{t}=\sum_{i=1}^{p} \Gamma_{i} Y_{t-1}+\varepsilon_{t}
$$

Where $Y_{t}$ is an $(n \times 1)$ vector of time series variables, $\Gamma_{i}$ are $(n \times n)$ coefficient matrices, while $\varepsilon_{t}$ is an $(n \times 1)$ vector of error terms. The optimal lag selection was based on the Schwarz (1978) and Hanna and Quinn (1979) criteria (see Table 3).

Lag selection was then adjusted based on the Lagrange Multiplier (LM) autocorrelation test to obtain non-autocorrelated error terms (see Table 4). The results indicate that five lags are the optimal selection for the model specified in this study.

All roots of the characteristic polynomial have a modulus less than one and lie inside the unit circle which indicates that the model is stable (see Table 5).

The Granger causality test was evaluated as the last step of the analysis. The significance of $p$-values for the Wald test statistic reveals that there is one-directional Granger-causality between Stocks Difference and Price Spread. It means that the difference between SMP and butter intervention stocks Granger-causes the butter/ SMP price spread, while the butter/SMP price spread does not Granger-cause the difference between SMP and butter intervention stocks. 
Olipra, J. (2020). Destabilizing intervention in EU dairy markets. J. Agribus. Rural Dev., 1(55), 73-83. http://dx.doi.org/ 10.17306/J.JARD.2020.01229

Table 3. VAR lag order selection criteria

\begin{tabular}{ccc}
\hline Lag & SC & HQ \\
\hline 0 & 29.164 & 29.134 \\
1 & 21.902 & 21.812 \\
2 & 21.217 & 21.068 \\
3 & $21.188^{*}$ & $20.979 *$ \\
4 & 21.258 & 20.989 \\
5 & 21.316 & 20.987 \\
6 & 21.458 & 21.069 \\
7 & 21.617 & 21.169 \\
8 & 21.742 & 21.234 \\
9 & 21.853 & 21.286 \\
10 & 21.974 & 21.346 \\
11 & 22.122 & 21.435 \\
12 & 22.228 & 21.481 \\
\hline
\end{tabular}

* indicates the lag order selected based on the criterion.

SC: Schwarz information criterion.

HQ: Hannan-Quinn information criterion.

Source: own calculations.

Table 4. VAR residual serial correlation LM test for VAR(5)

\begin{tabular}{ccc}
\hline Lags & LM-stat & Probability \\
\hline 1 & 3.939 & 0.414 \\
2 & 1.966 & 0.742 \\
3 & 3.804 & 0.433 \\
4 & 1.110 & 0.893 \\
5 & 4.117 & 0.390 \\
6 & 0.521 & 0.972 \\
7 & 7.157 & 0.128 \\
8 & 4.137 & 0.388 \\
9 & 1.448 & 0.836 \\
10 & 0.304 & 0.990 \\
11 & 0.729 & 0.948 \\
12 & 3.732 & 0.444 \\
\hline
\end{tabular}

Source: own calculations.
Table 5. Roots of the characteristic polynomial for VAR(5)

\begin{tabular}{cc}
\hline Root & Modulus \\
\hline $0.943-0.112 \mathrm{i}$ & 0.950 \\
$0.943+0.112 \mathrm{i}$ & 0.950 \\
0.937 & 0.937 \\
$0.676-0.539 \mathrm{i}$ & 0.865 \\
$0.676+0.539 \mathrm{i}$ & 0.865 \\
$-0.481-0.477 \mathrm{i}$ & 0.678 \\
$-0.481+0.477 \mathrm{i}$ & 0.678 \\
-0.639 & 0.639 \\
$-0.042-0.543 \mathrm{i}$ & 0.544 \\
$-0.042+0.543 \mathrm{i}$ & 0.544 \\
\hline
\end{tabular}

Source: own calculations.

Table 6. Granger causality test

\begin{tabular}{lcc}
\hline \multicolumn{1}{c}{ Null hypotheses } & Chi-sq & Probability \\
\hline $\begin{array}{l}\text { H1: Stocks Difference does not } \\
\text { Granger-cause Price Spread }\end{array}$ & 28.462 & 0.000 \\
$\begin{array}{l}\text { H2: Price Spread does not Granger- } \\
\text {-cause Stocks Difference }\end{array}$ & 3.088 & 0.686 \\
\hline
\end{tabular}

Source: own calculations.

\section{SENSITIVITY ANALYSIS}

The ordinary Wald test of joint significance of regression parameters, used as a causality test, is not valid if the variables are non-stationary. Therefore, in the light of the results of ADF and KPSS tests (see Table 2), it is imperative to test Granger causality also with the assumption that the variables are integrated of order one. The sensitivity analysis was started with the procedure by (Johansen and Juselius, 1992) in order to test for cointegration between variables. The results of the trace test and the maximum eigenvalue test suggest that there is one cointegrating vector indicating causality between the variables analyzed (see Table 7).

Then, the study employs the Granger causality approach developed by Toda and Yamamoto (1995). The method proposed by Toda and Yamamoto (1995) deals 
Table 7. Johansen cointegration tests

\begin{tabular}{lcccc}
\hline Hypothesized No. of CE(s) & Eigenvalue & Trace statistic & 0.05 critical value & Probability \\
\hline \multicolumn{5}{c}{ Unrestricted cointegration rank test (trace) } \\
None & 0.185 & 25.616 & 15.495 & 0.001 \\
At most 1 & 0.021 & 2.441 & 3.841 & 0.118 \\
\hline None & Unrestricted cointegration rank test (maximum eigenvalue) & 14.265 & 0.002 \\
At most 1 & 0.185 & 23.176 & 3.841 & 0.118 \\
\hline
\end{tabular}

Source: own calculations.

with the problem of nonstationarity of variables in two steps. In the first step, the standard $\operatorname{VAR}(k)$ model is estimated on the levels of variables, which was done in the previous section. Then, the correct VAR order $(k)$ is artificially augmented by the maximum order of integration of the time series $\left(d_{\max }\right)$ and the $\left(k+d_{\max }\right)$-th VAR order is estimated. Therefore, in this case, the new model would be VAR(6). Finally, the Wald test is performed, and the coefficients of the last lagged $d_{\max }$ vector are ignored. The modified Wald (MWALD) test has an asymptotic chi-square distribution with $(k)$ degrees of freedom for which well-founded inferences can be carried out.

The significance of the p-values for the modified Wald (MWALD) statistic confirm the results obtained on assumption that the analyzed variables are stationary. The difference between SMP and butter intervention stocks Granger-causes the butter/SMP price spread, while the butter/SMP price spread does not Grangercause the difference between SMP and butter intervention stocks (see Table 8).

Table 8. Toda-Yamamoto causality test

\begin{tabular}{lcc}
\hline \multicolumn{1}{c}{ Null hypotheses } & Chi-sq & Probability \\
\hline $\begin{array}{l}\text { H1: Stocks Difference does not } \\
\text { Granger-cause Price Spread }\end{array}$ & 13.420 & 0.020 \\
$\begin{array}{l}\text { H2: Price Spread does not Granger- } \\
\text { cause Stocks Difference }\end{array}$ & 3.642 & 0.602 \\
\hline
\end{tabular}

Source: own calculations.

\section{CONCLUDING REMARIS AND POLICY IMPLICATIONS}

The results of the research show that the difference between butter and SMP intervention stocks accumulated by the European Commission Granger-causes the butter/SMP price spread while there is no causality in the opposite direction. Therefore, the hypothesis that excessive intervention stocks of SMP vs. butter stocks accumulated by the European Commission are the reason why the spread between butter and SMP prices rose to exceptionally high levels cannot be rejected. In the light of the current literature, the above may suggest that following the integration of the EU dairy market with the global market, the EC intervention policy (financed by EU taxpayers) not only loses its efficiency (Heleine et al., 2016) but also may lead to severe market imbalances. According to the existing literature, the high volatility in the dairy market is here to stay (Keane and O'Connor, 2009; O'Connor et al., 2009; Weber et al., 2012; O'Connor et al., 2015). Hence, there is a need for developing market-based risk management tools for dairy market futures/options, insurance or capital buffers as a replacement for the current EU dairy policy based on conventional intervention measures. Some valuable remarks in this respect may be found in Kloosterboer (2016) and in the EC report (EC, 2017).

\section{SOURCE OF FINANCING}

Article financed by the author. 


\section{REFERENCES}

AHDB/DairyCo (2014). Review of Dairy Market Indicators. A report produced by Ken Burgess Associates on behalf of AHDB/DairyCo.

Amann, G., Lehecka, V., Schmid, E. (2013). Does speculation drive agricultural commodity spot prices? J. Aus. Soc. Agric. Econ., 22, 131-140.

EC (2017). Managing risk in the dairy sector: how futures markets could help, European Commission Agricultural Market Briefs, No. 11.

EU (2013). Council Regulation (EU) No 1370/2013 of 16 December 2013 determining measures on fixing certain aids and refunds related to the common organisation of the markets in agricultural products. Retrieved from: http:// data.europa.eu/eli/reg/2013/1370/oj

EU (2016). Council Regulation (EU) 2016/1042 of 24 June 2016 amending Regulation (EU) No 1370/2013 determining measures on fixing certain aids and refunds related to the common organisation of the markets in agricultural products, as regards the applicable quantitative limitation for the buying-in of skimmed milk powder. Retrieved from: http://data.europa.eu/eli/reg/2016/1042/oj

EU (2018). Council Regulation (EU) 2018/147 of 29 January 2018 amending Regulation (EU) No 1370/2013 as regards the quantitative limitation for buying-in skimmed milk powder. Retrieved from: http://data.europa.eu/eli/ $\mathrm{reg} / 2018 / 147 / \mathrm{oj}$

EU (2019). Commission Implementing Regulation (EU) $2017 / 1919$ of 19 October 2017 on the minimum selling price for skimmed milk powder for the 13th partial invitation to tender within the tendering procedure opened by Implementing Regulation (EU) 2016/2080. Retrieved from: http://data.europa.eu/eli/reg_impl/2017/1919/oj

EU Milk Market Observatory (2018). Data on EU dairy commodities prices, Retrieved from: https://ec.europa.eu/agriculture/market-observatory/milk

Food and Agriculture Organization (2017). Milk and Milk Products: Price and Trade Update, Rome, Retrieved from: http://www.fao.org/fileadmin/templates/est/COMM MARKETS_MONITORING/Dairy/Documents/Milk and_Milk_Products_June_2017.pdf

Gale, J. (2018). Fat Is Back and Premium Butter Makers Are Taking the Cream, Bloomberg. Retrieved from: https:// www.bloomberg.com/news/articles/2018-08-12/the-clunky-ugly-dad-shoe-gives-sneaker-makers-a-swift-kick

Granger, C. W. J. (1988). Some recent development in a concept of causality. J. Econom., 39(1), 199-211.

Hannan, E. J., Quinn, B. G. (1979). The Determination of the order of an autoregression. J. Royal Stat. Soc., 41(B), $190-195$.
Heleine, S., Santini, F., Enciso, S. R. A., Dillen, K., Dominguez, I. P. (2016). A stochastic approach of the assessment of EU intervention mechanisms for dairy products, paper presented at conference SFER LML, Clermont-Ferrand, June 9-10.

Johansen, S., Juselius, K. (1992). Testing structural hypotheses in a multivariate cointegration analysis of the PPP and the UIP for UK. J. Econom., 53(1), 211-244.

Jongeneel, R. A., Silvis, H. J., Verhoog, A. D., Daatselaar, C. H. G. (2018). Effects of selling public intervention stocks of skimmed milk powder. Wageningen, Wageningen Economic Research, Report 2018-046.

Keane, M., O'Connor, D. (2009). Price Volatility in the EU Dairy Industry: Causes, Consequences and Coping Mechanisms. Brussels: European Dairy Association.

Kloosterboer, W. (2016). Milk and dairy products' price volatility: EU dairy cooperatives attitude towards volatility. In: A. Garrido, B. Brümmer, R. M'Barek, M. P. M. Meuwissen, C. Morales-Opazo (Eds.), Agricultural Markets Instability. Revisiting the Recent Food Crises (pp. 143-150). Routledge: London and New York.

Newton, J. (2016). Price Transmission in Global Dairy Markets. Int. Food Agribus. Manag. Rev., 19, 57-72.

O’Connor, D., Keaneand, M., Barnes, E. (2009). Measuring Volatility in Dairy Commodity Prices. Paper prepared at the 113th EAAE Seminar: A resilient European food industry and food chain in a challenging world, Chania, Crete, September 3-6, 2009.

O'Connor, D., Bergmann, D., Keane, M. (2015). The challenges posed by price volatility in the EU dairy sector, Agrarian Perspectives XXIV and 25th Annual Conference of the Austrian Society of Agricultural Economics, Prague, 1618 September.

OECD-FAO (2018). OECD-FAO Agricultural Otlook 20182027, Data on global butter consumption. Retrieved from: https://stats.oecd.org/Index.aspx?DataSetCode=HIGH AGLINK_2017

Olipra, J. (2019). Change in Seasonality Patter of EU Farmgate Milk Price. Probl. World Agric., 19(3), 75-84.

Pouch, T., Trouvé, A. (2018). Deregulation and the crisis of dairy markets in Europe: facts for economic interpretation. Stud. Polit. Econ., 99(2), 194-212.

Regulation (EU) No 1308/2013 of the European Parliament and of the Council of 17 December 2013 establishing a common organisation of the markets in agricultural products and repealing Council Regulations (EEC) No 922/72, (EEC) No 234/79, (EC) No 1037/2001 and (EC) No 1234/2007. Retrieved from: http://data.europa. eu/eli/reg/2013/1308/oj

Schreijen, S., Bellamy, K. (2017). Rising Butter Prices: A Tough Cookie for the Cookie Industry, RaboResearch. 
Schwarz, G. (1978). Estimating the Dimension of a Model. The Annals of Statistics, 6(2), 461-464.

Terazono, E. (2017). Why butter prices are at a record high. Financial Times. Retrieved from: https:/www.ft.com/ content/8550f05a-6649-11e7-8526-7b38dcaef614

Toda, H. Y., Phillips, P. C. B. (1993). Vector Autoregressions and Causality. Econometrica, 61, 1367-1393.

Toda, H. Y., Yamamoto, T. (1995). Statistical inference in vector autoregressions with possibly integrated processes. J. Econom., 66, 225-250.

U.S. Census Bureau (2011). X-12-ARIMA Reference Manual. Washington DC: U.S. Census Bureau.
Weber, S. A, Salamon, P., Hansen, H. (2012). Volatile world market prices for dairy products - how do they affect domestic price formation: The German cheese market. Paper prepared for the 123rd EAAE Seminar: Price Volatility and Farm Income Stabilisation. Modelling Outcomes and Assessing Market and Policy Based Responses, Dublin, February 23-24.

Williams, J., Wright, B. (1991). Storage and Commodity Markets. Cambridge: Cambridge University Press. 